\title{
Effect of Freezing Treatment on Colostrum to Prevent the Transmission of Bovine Leukemia Virus
}

\author{
Toru KANNO ${ }^{1,2) *}$, Ryoko ISHIHARA ${ }^{3)}$, Shinichi HATAMA ${ }^{3)}$, Yasuhiro OUE ${ }^{4)}$, Hiroki EDAMATSU ${ }^{5}$, \\ Yasuhiro KONNO ${ }^{6}$, Satoshi TACHIBANA ${ }^{7)}$ and Kenji MURAKAMI ${ }^{8)}$ \\ ${ }^{1)}$ Exotic Disease Research Division, National Institute of Animal Health, 6-20-1 Josuihoncho, Kodaira, Tokyo 187-0022, Japan \\ ${ }^{2)}$ United Graduate School of Veterinary Sciences, Gifu University, 1-1 Yanagido, Gifu 501-1193, Japan \\ 3)Hokkaido Research Station, National Institute of Animal Health, 4 Hitsujigaoka, Toyohira, Sapporo, Hokkaido 062-0045, Japan \\ 4)Hokkaido Kushiro Livestock Hygiene Service Center, 127-1 Otanoshike, Kushiro, Hokkaido 084-0917, Japan \\ ${ }^{5)}$ Hokkaido Rumoi Livestock Hygiene Service Center, 6-1 Motomachi, Horonobe-cho, Teshio-gun, Hokkaido 098-3217, Japan \\ ${ }^{6}$ Hokkaido Hidaka Livestock Hygiene Service Center, 2-88-5 Shizunai-asahi-cho, Shinhidaka-cho, Hidaka-gun, Hokkaido 056-0003, Japan \\ ${ }^{7)}$ Hokkaido Iburi Livestock Hygiene Service Center, 4-3 Tomiura, Noboribetsu, Hokkaido 059-0463, Japan \\ ${ }^{8)}$ Department of Veterinary Medicine, Faculty of Agriculture, Iwate University, 3-18-8 Ueda, Morioka, Iwate 020-8550, Japan
}

(Received 19 May 2013/Accepted 12 September 2013/Published online in J-STAGE 26 September 2013)

ABSTRACT. Here, we used a sheep bioassay to determine the effect of freezing colostrum to prevent the transmission of bovine leukemia virus (BLV) among neonatal calves. Leukocytes were isolated from the colostrum of a BLV-infected Holstein cow and were then either left untreated (control) or freeze-thawed. A sheep inoculated intraperitoneally with the untreated leukocytes was infected with BLV at 3 weeks after inoculation, whereas the sheep inoculated with treated leukocytes did not become infected. The uninfected sheep was inoculated again with leukocytes isolated from the colostrum of another BLV-infected Holstein cow after freezing treatment, and again it did not become infected with BLV. Finally, this sheep was inoculated with the leukocytes isolated from the colostrum of another virus-infected cow without freezing treatment, and it became infected with BLV at 4 weeks after inoculation. The results indicate that colostrum should be frozen as a useful means of inactivating the infectivity of BLV-infected lymphocytes.

KEY WORDS: bovine leukemia virus, colostrum, freezing treatment, sheep bioassay.

doi: 10.1292/jvms.13-0253; J. Vet. Med. Sci. 76(2): 255-257, 2014

Enzootic bovine leukosis (EBL) is a contagious disease of cattle caused by the bovine leukemia virus (BLV), which belongs to the genus Deltaretrovirus in the family Retroviridae [17]. Most BLV infections are asymptomatic with approximately 30 to $40 \%$ of infected cattle developing persistent lymphocytosis (PL), while less than 5\% develop malignant lymphosarcoma [16]. BLV infection has a worldwide distribution [16]; however, several countries in Europe have successfully eradicated BLV through changes in management procedures, such as test-and-slaughter control programs [1, $14]$.

The first large-scale epidemiological survey of BLV in cattle was carried out in 1982 in Japan, and the second survey was conducted during 2007, evaluating a total of 5,420 cattle from 209 farms in seven prefectures [12]. The survey showed that the prevalence of BLV infection was $28.6 \%$, a 4-fold increase compared with the previous study [8]. Although the reason for the spread of BLV infection in Japan was not clarified, it is essential to provide preventive measures to minimize the risk of BLV infection, as well as

*Correspondence to: Kanno, T., Exotic Disease Research Division, National Institute of Animal Health, 6-20-1 Josuihoncho, Kodaira, Tokyo 187-0022, Japan. e-mail: kannot@affrc.go.jp

(C)2014 The Japanese Society of Veterinary Science

This is an open-access article distributed under the terms of the Creative Commons Attribution Non-Commercial No Derivatives (by-nc-nd) License $<$ http://creativecommons.org/licenses/by-nc-nd/3.0/>. to conduct a surveillance study to identify major risk factors. BLV infects lymphocytes and integrates a DNA intermediate as a provirus into the genome of the cells. The cell-free virus is rarely detected in vivo and is thought to appear during acute infection stages before neutralizing antibody production and the period of pregnancy that cause in utero infection. [4]. Therefore, most BLV transmission occurs through the transfer of BLV-infected lymphocytes among cattle. Many potential routes of BLV transmission exist; however, the role of colostrum ingestion during natural transmission remains unclear. Previous studies have suggested reciprocal roles. Colostrum and milk from BLV-infected cattle contain BLVinfected cells that may cause infection in neonatal calves from uninfected dams $[6,11,15]$. In contrast, antibodies in the colostrum protect against neonatal infection $[10,13,15$, 18]. In several studies of dairy herds, the transmission rate of colostrum and milk in calves by 6-12 months of age was approximately $6-16 \%$ in dairy herds [7]. Feeding management for neonatal calves influenced the risk of colostrum ingestion for the transmission of BLV, although the significance of this risk is uncertain.

An in vitro infectivity assay for BLV has been developed using several monolayer cultures, such as fetal bovine lung cells and CC81 cells [9], in which syncytiums are induced. However, because of frequent bacterial content in colostrum, this assay is not considered appropriate for use in studies investigating the inactivation of BLV. On the other hand, sheep are highly susceptible to experimental inoculation 
and are more prone to tumor development at a younger age compared with cattle, in addition to appearing resistant to the bacteria present in colostrum. Therefore, previous studies have successfully demonstrated the utility of using a sheep bioassay to study the frequency with which BLV and BLV infected cells may be detected in colostrum and milk from cows naturally infected with the virus $[6,11]$.

Both heating and freezing treatments have been considered as techniques to inactivate BLV-infected lymphocytes in colostrum. The effect of heat treatment has been elucidated [2]; however, the effect of freezing treatment has not been elucidated in vivo so far. Therefore, here, we used a sheep bioassay to elucidate the effect of freezing colostrum to prevent the transmission of BLV among neonatal calves.

Recipient sheep were born at the Hokkaido Research Station, National Institute of Animal Health. The Animal Care and Use Committee of the National Institute of Animal Health approved all animal procedures prior to initiation of this study. At the start of the study, none of the sheep were positive for BLV antibodies based on an agar gel immunodiffusion (AGID) test (Kitasato Daiichi Sankyo Vaccine, Saitama, Japan) using the virion glycoprotein antigen. The sheep were housed in an insect-proof isolation facility during the experiments. To obtain colostrum, we conducted a serum survey of BLV infection in cattle at several farms and monitored the BLV copy number in the lymphocytes of peripheral blood of pregnant cows at regular intervals. Real-time PCR was performed to determine the BLV copy number by using a CycleavePCR bovine leukemia virus detection kit (TaKaRa, Tokyo, Japan). Colostrum was obtained immediately after parturition from a BLV-infected Holstein cow that had a high BLV copy number in its peripheral blood mononuclear cells (PBMCs) (Table 1). For the inoculum, we used cells isolated from colostrum, which is a more efficient and rapid technique compared with whole milk inoculum [6].

Two liters of colostrum was obtained from cow A, which were separated for the two inoculation treatments, i.e., with and without freezing. For the freezing treatment, colostrum was frozen at $-25^{\circ} \mathrm{C}$ for one night and then thawed. One liter of colostrum from each of the two treatments was centrifuged at $2,800 \times g$ for $15 \mathrm{~min}$ to remove butterfat. Then, the aqueous phase and pellets were suspended and centrifuged at 2,800 $\times g$ for a further $15 \mathrm{~min}$. The pellets were suspended with phosphate-buffered saline (PBS) and washed once via centrifugation. The pellet cells were resuspended with PBS and were then used to inoculate the sheep intraperitoneally.

Blood samples were obtained from the sheep at weekly intervals, and PCR was used to detect BLV in the lymphocytes [5], while an AGID and passive hemagglutination assay (PHA) (Nisseiken, Tokyo, Japan) were used to detect antibodies to BLV in serum.

Sheep No.163 was inoculated with cells (approximately 3 $\times 10^{8}$ cells) obtained from the $1 l$ of untreated colostrum of cow A, which had 1,398 copies per $10 \mathrm{ng}$ of DNA of PBMCs. This sheep tested positive for BLV at 3 weeks after inoculation using PCR and at 5 weeks using the AGID and PHA tests. In comparison, sheep No. 164 was inoculated with cells (approximately $4.8 \times 10^{8}$ cells) from $1 l$ of freeze-thaw-
Table 1. BLV copy number of the peripheral blood mononuclear cells

\begin{tabular}{cc}
\hline Pregnant cow & BLV copy number (per 10 $n$ g of DNA) ${ }^{\mathrm{a})}$ \\
\hline A & 1,398 \\
B & 611 \\
C & 925 \\
\hline
\end{tabular}

a) BLV copy numbers were determined by using a CycleavePCR bovine leukemia virus detection kit (TaKaRa, Tokyo, Japan), which quantified the copy number per $10 \mathrm{ng}$ of DNA in total DNA isolated from peripheral blood mononuclear cells.

Table 2. Results of the genomic and serologic tests of sheep inoculated with cells from the colostrum of cow A

\begin{tabular}{ccccccccc}
\hline \multirow{2}{*}{$\begin{array}{c}\text { Weeks after } \\
\text { inoculation }\end{array}$} & \multicolumn{3}{c}{$163^{\mathrm{a}} \mathrm{n}$} & & \multicolumn{3}{c}{$164^{\mathrm{b})}$} \\
\cline { 2 - 4 } \cline { 6 - 8 } & PCR & AGID & PHA & & PCR & AGID & PHA \\
\hline 1 & - & - & - & & - & - & - \\
2 & - & - & - & & - & - & - \\
3 & + & - & - & & - & - & - \\
4 & + & - & - & & - & - & - \\
5 & + & + & + & & - & - & - \\
6 & + & + & + & & - & - & - \\
7 & + & + & + & & - & - & - \\
8 & + & + & + & & - & - & - \\
9 & + & + & + & & - & - & - \\
\hline
\end{tabular}

a) No. 163 was inoculated with cells (approximately $3 \times 10^{8}$ cells) from untreated colostrum. b) No. 164 was inoculated with cells (approximately $4.8 \times 10^{8}$ cells) from freeze-thaw-treated colostrum.

treated colostrum from cow A and remained BLV negative in all tests until 9 weeks after inoculation (Table 2). The BLV copy numbers in the untreated and freeze-thaw-treated colostrum of cow A were determined by real-time PCR assay. The assay showed $1.5 \times 10^{6}$ and $1.4 \times 10^{6}$ copies per liter, respectively (data not shown). These results suggest that BLV proviral DNA remained in the inoculum after freeze-thaw treatment. The sheep was inoculated again with cells (approximately $8.9 \times 10^{8}$ cells) from $1 l$ of freeze-thaw-treated colostrum from cow $\mathrm{B}$, which had 611 copies per $10 \mathrm{ng}$ of DNA of PBMCs, and remained BLV negative in all tests until 29 weeks after inoculation (data not shown). Finally, the sheep, No.164, was inoculated with cells (approximately $4.8 \times 10^{9}$ cells) from 1.7 liters of untreated colostrum from cow $\mathrm{C}$, which had 925 copies per $10 \mathrm{ng}$ of DNA of PBMCs. The sheep tested positive for BLV at 4 weeks after inoculation using PCR and at 6 weeks for the AGID and PHA tests (Table 3).

A recent seroepidemiological study in Japan confirmed that BLV is more widespread in dairy cattle compared with beef breeding cattle [12]. This difference is probably due to the common practice of feeding bulk milk to calves that are not protected by maternal antibodies at dairy farms [3]. For instance, in Brazilian dairy herds, $27.3 \%$ of calves born from BLV-negative dams that were fed pooled milk from BLVinfected cows became BLV positive, whereas similar calves fed pooled milk from BLV-free cows remained negative. In comparison, $16.7 \%$ of calves born from BLV-infected 
Table 3. Results of the genomic and serologic tests of sheep inoculated with cells from the colostrum of cow C

\begin{tabular}{cccc}
\hline $\begin{array}{c}\text { Weeks after } \\
\text { inoculation }\end{array}$ & \multicolumn{3}{c}{$164^{\mathrm{a})}$} \\
\cline { 2 - 4 } & PCR & AGID & PHA \\
\hline 1 & - & - & - \\
2 & - & - & - \\
3 & - & - & - \\
4 & + & - & - \\
5 & + & - & - \\
6 & + & + & + \\
7 & + & + & + \\
\hline
\end{tabular}

a) No. 164 was inoculated with cells (approximately $4.8 \times 10^{9}$ cells) from untreated colostrum.

dams that received colostrum from their dams and were fed pooled milk from BLV-infected cows became BLV positive, whereas the susceptibility of similar calves fed pooled milk from BLV-free cows was $8.7 \%$ [15]. It has been suggested that colostrum and pooled milk increase the risk of BLV transmission, whereas the antibodies in colostrum decrease the risk of infection. Therefore, experiments to reduce the risk of infection and identify the optimal conditions for the treatment of pooled colostrum are required. The results of the current study demonstrated that the freezing treatment for colostrum provides a viable means of inactivating the infectivity of BLV-infected lymphocytes. These data could be used in development of an effective BLV control program by veterinarians and farmers.

ACKNOWLEDGMENTS. The authors would like to thank Mr. Keiji Itoh, Mr. Kazuhiko Takase, Mr. Mitsutoshi Noi and Mr. Yoshihiro Himoro for their skilled handling of the animals at the Institute of Animal Health, Hokkaido Research Center.

\section{REFERENCES}

1. Acaite, J., Tamosiunas, V., Lukauskas, K., Milius, J. and Pieskus, J. 2007. The eradication experience of enzootic bovine leukosis from Lithuania. Prev. Vet. Med. 82: 83-89. [Medline] [CrossRef]

2. Baumgartener, L., Olson, C. and Onuma, M. 1976. Effect of pasteurization and heat treatment on bovine leukemia virus. $J$. Am. Vet. Med. Assoc. 169: 1189-1191. [Medline]

3. Dimmock, C. K., Chung, Y. S. and MacKenzie, A. R. 1991. Factors affecting the natural transmission of bovine leukaemia virus infection in Queensland dairy herds. Aust. Vet. J. 68: 230-233. [Medline] [CrossRef]
4. Evermann, J. F., Digiacomo, R. F. and Hopkins, S. G. 1987. Bovine leukosis virus - understanding viral transmission and the methods of control. Vet. Med. 82: 1051-1058.

5. Fechner, H., Blankenstein, P., Looman, A. C., Elwert, J., Geue, L., Albrecht, C., Kurg, A., Beier, D., Marquardt, O. and Ebner, D. 1997. Provirus variants of the bovine leukemia virus and their relation to the serological status of naturally infected cattle. Virology 237: 261-269. [Medline] [CrossRef]

6. Ferrer, J. F., Kenyon, S. J. and Gupta, P. 1981. Milk of dairy cows frequently contains a leukemogenic virus. Science 213: 1014-1016. [Medline] [CrossRef]

7. Hopkins, S. G. and DiGiacomo, R. F. 1997. Natural transmission of bovine leukemia virus in dairy and beef cattle. Vet. Clin. North Am. Food Anim. Pract. 13: 107-128. [Medline]

8. Ito, T. 1987. Statistics on regional prevalence of gp antibody against bovine leukosis virus in Japan. Bull. Natl. Inst. Anim. Health 90: 35-60.

9. Itohara, S. and Mizuno, Y. 1984. Dimethyl sulfoxide enhances syncytium formation induced by bovine leukemia virus. Microbiol. Immunol. 28: 251-255. [Medline]

10. Lassauzet, M. L., Johnson, W. O., Thurmond, M. C. and Stevens, F. 1989. Protection of colostral antibodies against bovine leukemia virus infection in calves on a California dairy. Can. J. Vet. Res. 53: 424-430. [Medline]

11. Miller, J. M. and Van der Maaten, M. J. 1979. Infectivity tests of secretions and excretions from cattle infected with bovine leukemia virus. J. Natl. Cancer Inst. 62: 425-428. [Medline]

12. Murakami, K., Kobayashi, S., Konishi, M., Kameyama, K., Yamamoto, T. and Tsutsui, T. 2011. The recent prevalence of bovine leukemia virus (BLV) infection among Japanese cattle. Vet. Microbiol. 148: 84-88. [Medline] [CrossRef]

13. Nagy, D. W., Tyler, J. W. and Kleiboeker, S. B. 2007. Decreased periparturient transmission of bovine leukosis virus in colostrum-fed calves. J. Vet. Intern. Med. 21: 1104-1107. [Medline] [CrossRef]

14. Nuotio, L., Rusanen, H., Sihvonen, L. and Neuvonen, E. 2003. Eradication of enzootic bovine leukosis from Finland. Prev. Vet. Med. 59: 43-49. [Medline] [CrossRef]

15. Romero, C. H., Cruz, G. B. and Rowe, C. A. 1983. Transmission of bovine leukaemia virus in milk. Trop. Anim. Health Prod. 15: 215-218. [Medline] [CrossRef]

16. Schwartz, I. and Levy, D. 1994. Pathobiology of bovine leukemia virus. Vet. Res. 25: 521-536. [Medline]

17. Stoye, J. P., Blomberg, J., Coffin, J. M., Fan, H., Hahn, B., Neil, J., Quackenbush, S., Rethwilm, A. and Tristem, M. 2012. Family Retroviridae. pp. 477-495. In: Virus Taxonomy, Ninth Report of the International Committee on Taxonomy of Viruses (King, A. M. Q., Adams, M. J., Carstens, E. B. and Lefkowitz, E. J. eds.), Elsevier/Acamemic Press, Waltham.

18. Van Der Maaten, M. J., Miller, J. M. and Schmerr, M. J. 1981. Effect of colostral antibody on bovine leukemia virus infection of neonatal calves. Am. J. Vet. Res. 42: 1498-1500. [Medline] 